\title{
СОЧЕТАНИЕ СПОСОБОВ ПРЕДВАРИТЕЛЬНОГО ИЗУЧЕНИЯ ВЧР И ИНТЕРАКТИВНОЙ КОРРЕКЩИИ СТАТИКИ В ПРОЦЕССЕ ОБРАБОТКИ ДЛЯ УЧЕТА ПОВЕРХНОСТНЫХ НЕОДНОРОДНОСТЕЙ НА ПРИМЕРЕ ДАННЫХ ПРЕДГОРНОГО РАЙОНА ЗАПАДНОГО УЗБЕКИСТАНА.
}

${ }^{1}$ Козырев В.С., ${ }^{2}$ Мамадалиев ТЖ., 'Коротков И.П., 'Свистова Е.Л., 'Бурлаков А.В. $\lambda^{\prime}$ - OOO «Геофизические Системы Данных», Москва, ${ }^{2}-$ CП "GISSARNEFTGAZ»)

Проблема учета неоднородностей верхней части разреза (ВЧР) при обработке общеизвестна и является частью общей задачи определения параметров среды по характеристикам отраженнытх сигналов. Поскольку данные о ВЧР при разведке глубоких границ не имеют обычно самостоятельной разведочной ценности, изучению поверхностньх отложений гри сейсморазведочных работах уделяется, как правило, неоправданно мало внимания. Так как возможности выявления и учета поверхностньх неоднородностей по материалам основной съемки вследствие возникающих неоднозначностей имекот принципиальные ограничения, результатом экономии на проведении исследований ВЧР во многих районах являются недопустимые ошибки в огределении глубины отражающих границ, скоростных характеристик слоев, искажения динамических параметров, а иногда и невозможность выделения отраженньхх сигналов.

Целью работы явилось изучение влияния изученности ВЧР на последующую коррекцию статики на примере даннбг 3D предгорного района Западного Узбекистана. Исследуемая площадь по поверхностным условиям является предгорной адырной зоной со сложно-пересеченным рельефом, превышение рельефа восточных конщов относительно западных наqал составляет более $200 \mathrm{M}$. Одной из особенностей сейсмического волнового поля является сильная зашумленность данных и наличие значителькых временныг сдвигов, вызванных, повидимому, выходом на поверхность высокоскоростных коренных пород. Влияние настолько высоко, что на кореллограммах целевые отражения практически не выделяются.

Поскольку изучение ЗМС методом преломленных волн (МПВ-ЗМС) имеет ограниченную глубинность, а отработанные единичные МСК имеют глубину до $80 \mathrm{M}$, то одной из проблем обработки стало составление скоростной модели верхней части разреза (ВЧР), имеюшей 200 метровую и более толщину до единой и принятой для района работ линии приведения с альтитудой +390 м. Изучение данных МПВ показало, что внутри отмеченной толщи существует ряд преломляющих границ, граничная скорость по которым изменяется в широких пределах от $2000 \mathrm{~m} / \mathrm{c}$ до $3500 \mathrm{~m} / \mathrm{c}$.

В работе были опробованы и проанализированы различные способы учета верхней части разреза. В связи с плохим качеством данных пришлось отказаться от методов использующих для расчета первые вступления, в связи с их плохой прослеживаемостью. Априорные поправки переданные заказчиком тоже не дали удовлетворительного результата. Расчет поправок за рельеф с постоянной скоростью не дал положительных результатов из-за сильной неоднородности скоростного поля. В ре- зультате тестирования вылснилось, что качественное суммирование возможно при применении поправок за рельеф, полученных с использованием переменной по площади скоростью замешения вычисленной с использованием данных МПВ. Это, повидххмому, связанно с большими перепадами высот и изменением состава пород ВЧР в пределах всей плошади.

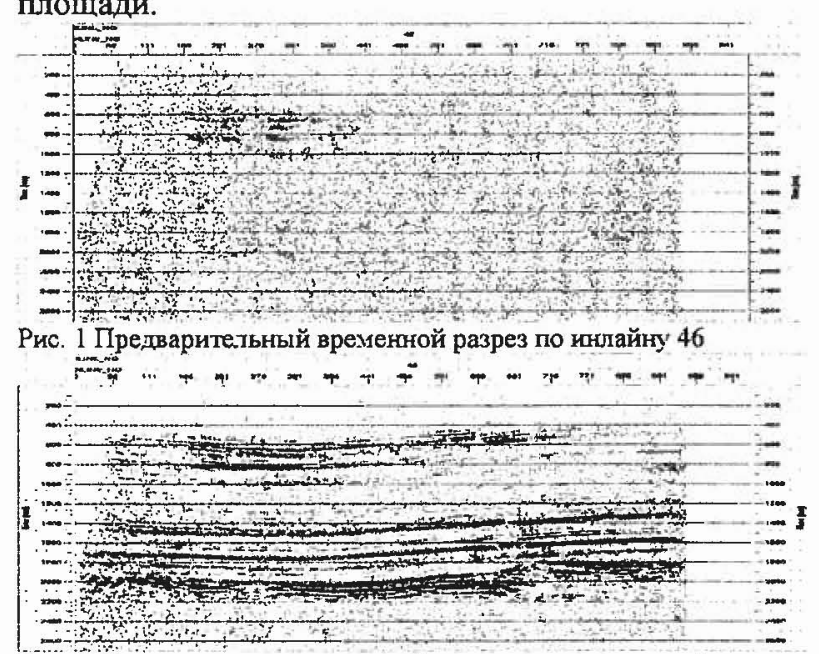

Рис. 2 Вертикальное сечение куба после интерактивной коррекции статических поправок по инлайну 46.

В результате анализа различных способов учега верхней части разреза были сделаны следующие выводы:

Работы по изучению ВЧР необходимы при наличии протяженных неоднородностей, больших по величине временных сдвигов, в условиях низкого отношения сигнал/помеха. Работы по изучению ВЧР необходимы для избежания ошибок построения скоростной модели ВЧР.

Использование дополнительных данных по изучению ВЧР улучшает прослеживаемость горизонтов в условиях низкого отношения сигнал/помеха и делает возможным проводить интерактивную коррекцию статики (рис.1,2.).

Авторы выражают благодарность CП «GISSARNEFTGAZ» за предоставленные данные.

\section{ЛИТЕРАТУРА}

Козырев В.С., Жуков А.П., Коротков И.П., Жуков А.А., Штеерсон М.Б. Ухет неоднородностей верхней части разреза в сейсморазведке. М. ООО «Недра-Бизнесцентр» 2003. 